\begin{tabular}{cc|c}
\hline Tar. Bil. Der. & Tarım Bilimleri Dergisi & Journal of Agricultural Sciences \\
& $\begin{array}{c}\text { Dergi web sayfası: } \\
\text { www.agri.ankara.edu.tr/dergi }\end{array}$ & Journal homepage: \\
& www.agri.ankara.edu.tr/journal
\end{tabular}

\title{
Effect of Infrared, Ultraviolet-C Radiations and Vacuum Drying on Certain Chemical and Microbial Characteristics of Stuffed Pasta (Manti)
}

\author{
Suleyman GOKMEN ${ }^{a}$, Aytac KOCABAS ${ }^{b}$, Ibrahim SAVRAN ${ }^{b}$, Abdulvahit SAYASLAN ${ }^{c}$, Mehmet Fatih \\ AYDIN $^{d}$, Hasan YETIM \\ ${ }^{a}$ Department of Food Processing, Technical Vocational School of Karamanoglu Mehmetbey University, 70100, Karaman, TURKEY \\ ${ }^{b}$ Department of Biology, Karamanoglu Mehmetbey University, 70100, Karaman, TURKEY \\ ${ }^{c}$ Department of Food Engineering, Karamanoglu Mehmetbey University, 70100, Karaman, TURKEY \\ ${ }^{d}$ Department of Public Health, Faculty of Health Science, Karamanoglu Mehmetbey University, 70100, Karaman, TURKEY \\ ${ }^{e}$ Department of Food Engineering, Istanbul Sabahattin Zaim University, 34200, Istanbul, TURKEY
}

\section{ARTICLE INFO}

Research Article

DOI: 10.15832 /ankutbd.539010

Corresponding Author: Suleyman GOKMEN, E-mail: sugokmen42@hotmail.com, Tel: +90 (338) 2262000

Received: 27 December 2017, Received in Revised Form: 11 May 2018, Accepted: 29 May 2018

\begin{abstract}
Stuffed pasta (manti) is one of the famous and nutritious traditional foods produced and consumed in Turkey. Traditional foods are special products having some cultural aspects of specific regions of countries. In addition to home-made traditional production, industrial production of manti has increased in recent years. Industrial production of manti using various techniques is likely to result in some risks or modifications in terms of its sensory and microbiological features. Therefore, the purpose of this study was to examine quality properties of manti samples produced by sole or combined applications of infrared (IR) and ultraviolet-C (UV-C) radiations and vacuum drying as compared to the traditional oven drying method. With this aim, some food-borne pathogens (Escherichia coli, Staphylococcus aureus, Salmonella typhimurium and Listeria monocytogenes) were inoculated into the manti recipe prior to the production. Afterwards, the samples were dried with 17 different IR, UV-C and vacuum drying combinations, including the traditional oven drying method. In addition to the, total microorganisms and food-borne pathogens, some chemical analyses like Thiobarbituric acid (TBA) measurement as an indicator of lipid oxidation was also studied. In the results, application of $500 \mathrm{~W}$ IR drying method produced satisfactory results in terms of microbiological quality. Again, a bar-type IR drying method at constant temperature $\left(150^{\circ} \mathrm{C}\right)$ seems to be a promising drying method for the industrial manti production. In conclusion, it might be suggested that IR drying method can be an alternative to the conventional method in industrial manti production.

Keywords: Manti; IR; UV-C; Vacuum; Drying; Pathogen bacteria
\end{abstract}

(C) Ankara Üniversitesi Ziraat Fakültesi

\section{Introduction}

Traditional foods are special products carrying cultural trends of certain localities and emerged from human experiences during hundreds of years without using modern technology (Gallegos-Infante et al 2010). Manti is one of the traditional foods with high nutritional value and widespread consumption in Turkey. It is a ground meat stuffed pasta product and marketed in fresh or mostly in dried forms. The manti process includes the following basic steps: 
(1) meatball preparation with ground meat and spices for fillings, (2) preparation of a stiff dough, (3) sheeting and cutting the dough, (4) placing the fillings on the sheeted dough and enclosing and then (5) drying or cooking (Heldman \& Lund 2007; Gokmen et al 2015; Sitti 2011).

Ground beef is the primary ingredient for microbial spoilage of manti. Therefore, in industrial production, heat treatment is included in the drying process. Drying is among the food preservation methods to decrease chemical, enzymatic and microbiological spoilage of the foods (Varlık et al 2004). Non-thermal food processing techniques are also used in contemporary industrial food preservation practices. For example, irradiation techniques are among these methods as an alternative to heat treatment. Again, utilization of new techniques, such as IR and UV-C, is essential for processing of foods at lower temperatures for higher quality product. Irradiation techniques are usually classified by wavelength. The main irradiation processes are performed by using infrared (IR) or ultraviolet (UV) spectra. The IR radiation is classified according to its wavelength as near IR (0.75-3 $\mu \mathrm{m})$, mid IR (3-25 $\mu \mathrm{m})$ and far IR (25-1000 $\mu \mathrm{m})$ (Singh \& Goswami 2003). The advantages of IR application include short processing time, energy efficiency, uniform product temperature, highquality product, high degree of process control, high value of heat transfer coefficient and environmental friendly nature (Farkas 1990; Erdogdu \& Ekiz 2011). The IR is used as a drying technique and tends to spread rapidly today. The UV radiation is also defined as a radiant energy form released from the sun. It is also divided into three groups; UV-A (320-400 nm), UV-B (280-320 nm) and UV-C (200$280 \mathrm{~nm}$ ). Having the highest germicidal activity, the $\mathrm{UV}-\mathrm{C}$ is the mainly used form of UV radiation in the food industry (Gokmen et al 2014).

Consumer demands from food production have changed considerably in recent years, usually they prefer uniform, healthy and high-quality food products. During the industrialization of traditional foods like manti, quality criteria could not be sustained through the whole process (Gokmen et al 2015). Indeed, it is difficult to achieve standard sensory quality when it comes to traditional foods (Cayot 2007). Therefore, the purpose of this study was to investigate the effects of sole or combined applications of IR and UV-C radiations and vacuum drying in industrial manti production. Hence, these non-thermal processes may ensure sustainable quality and may provide invaluable information as compared to the traditional manti production methods.

\section{Material and Methods}

\subsection{Material}

\subsubsection{Preparation of manti samples}

Manti samples were prepared in the laboratory following the traditional processing steps (Gökmen et al 2015) as follows:

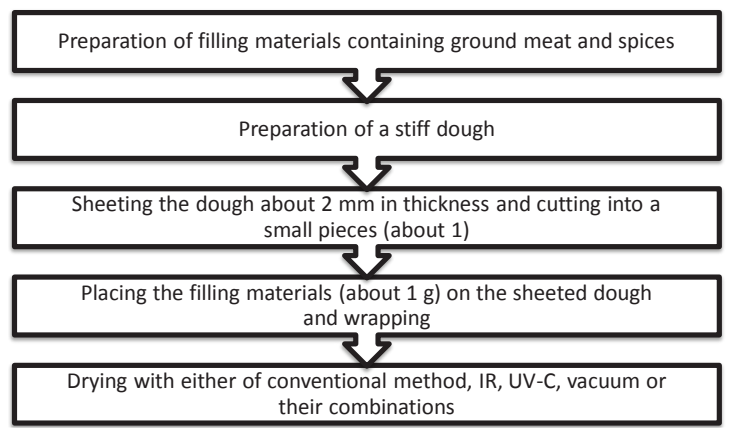

\subsection{Methods}

\subsubsection{IR and UV-C drying system and treatment of manti samples}

For this research, the IR oven dryer system was designed with four main subunits: IR lamps (250 $\mathrm{W}$ and/or $500 \mathrm{~W}$, short and medium wavelength), UV-C lamps and vacuum unit (20 kpa) (Figure 1). An analytical balance, a thermocouple and a thermohygrometer were also mounted inside the oven system to measure the weight-loss, temperature and relative humidity respectively. Again, the IR and UV-C radiation intensities were measured using a pyrometer located inside the oven. Prior to drying applications, UV lamps and IR lambs were turned on 
for about 15 and 5 minutes respectively to equilibrate the radiation. Stainless steel sample trays were used to hold the manti samples. The distance between the sample tray and the lamps was $25 \mathrm{~cm}$. The manti samples were dried in this system until their moisture contents were reduced to about $12 \%$. A total of 17 different combinations of drying methods UV-C, IR [250, $500 \mathrm{~W}$ and different wavelengths (shortwavelength: $0.76-2 \mu \mathrm{m}$, medium- wavelength: $2-4$ $\mu \mathrm{m})]$ and vacuum applications were used to treat the samples (Table 1). Traditional method was applied as dry hot air at $250^{\circ} \mathrm{C}, 30-35 \mathrm{~min}$.

\subsubsection{Ray intensity and energy consumption}

Ray intensity and energy consumptions were determined with the aim of finding whether IR and UV-C applications had advantages over the traditional oven drying method. For this purpose,

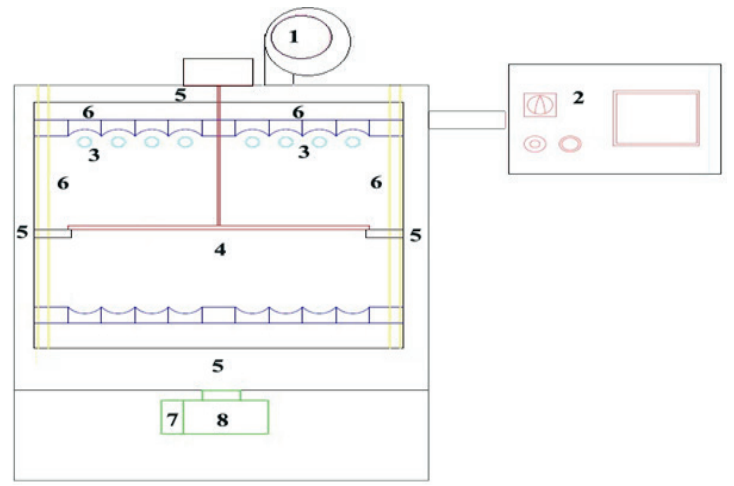

Figure 1- The designed IR dryer and its sections or components (1, the machine body; 2 , heating plate; 3, lamps (IR and UV-C); 4, scales and tray; 5 , suction fan; 6, calpe; 7, vacuum indicator; 8 , vacuum pump)

Table 1- Mean ray density and energy consumption for the corresponded applications

\begin{tabular}{|c|c|c|c|c|}
\hline Drying method & Drying type & $\begin{array}{c}\text { Mean ray } \\
\text { density } \\
\left(W m^{-2}\right)\end{array}$ & $\begin{array}{c}\text { Mean energy } \\
\text { consumption } \\
\text { (Turkish penny) } \\
\text { (TL } 100 \mathrm{~g}^{-1} \text { manti) }\end{array}$ & $\begin{array}{c}\text { Average investment } \\
\text { costs of the } \\
\text { dryers (TRY) }\end{array}$ \\
\hline \multirow{8}{*}{ FIR lamp* } & 250 W M Type IR** & 1500 & 0.33 & \multirow[t]{8}{*}{$12.000 * * * *$} \\
\hline & 250 W M Type IR+UV-C & 1100 & 0.38 & \\
\hline & 250 W M Type IR+vacuum*** & 1200 & 0.38 & \\
\hline & 250 W M Type IR+UV-C+vacuum & 1150 & 0.44 & \\
\hline & 500 W B Type IR** & 2280 & 0.46 & \\
\hline & 500 W B Type IR+UV-C & 2500 & 0.53 & \\
\hline & 500 W B Type IR+vacuum & 2350 & 0.53 & \\
\hline & 500 W B Type IR+UV-C+vacuum & 2280 & 0.49 & \\
\hline \multirow{8}{*}{ MDIR lamp } & 250 W B Type IR & 1500 & 0.33 & \\
\hline & 250 W B Type IR+UV-C & 1250 & 0.39 & \\
\hline & 250 W B Type IR+vacuum & 1500 & 0.39 & \\
\hline & 250 W B Type IR+UV-C+vacuum & 1200 & 0.43 & \\
\hline & 500 W M Type IR & 2700 & 0.47 & \\
\hline & 500 W M Type IR+UV-C & 2480 & 0.55 & \\
\hline & 500 W M Type $\mathrm{p}$ IR+vacuum & 2620 & 0.54 & \\
\hline & 500 W M Type IR+UV-C+vacuum & 2600 & 0.51 & \\
\hline Traditional method & $250^{\circ} \mathrm{C}$ for $30-35 \mathrm{~min}$ & - & 0.51 & 17.000 \\
\hline
\end{tabular}

*, FIR Far-Infrared lamp; MDIR, Middle-Infrared lamp; **, M Mushroom Type IR lamp, B Bar Type IR lamp; UV-C, Ultraviolet-C, $254 \mathrm{~nm} \lambda$; ***, vacuum: $20 \mathrm{KPa}$; W, watt, Formula 1 and 2 were used for calculation of energy consumption. Market conditions were researched for determine of dryer cost; $\mathrm{Kr}$, kuruş; ****, the total cost of the laboratory-type IR dryer, including all lamps and vacuum system; -, the ray intensity was not measured for traditional method 
the beam intensity was measured in $\mathrm{W} \mathrm{m}^{-2}$ with a portable pyrometer (Apogee Instruments, Model Mp-200, USA). In addition, the current passing

$W($ Watt $)=u($ Volt $) \times I$ (Amper) $\mathrm{x} t$ (time-hour)

Energy consumption= Power $(\mathrm{kW}) \mathrm{x}$ Time (hour) $\mathrm{x}$ Price (Turkish penny) through the dryer was measured with an ammeter (Set Ac-Dc, Amp 06) and the energy consumption was calculated using the following equations;

\subsection{Chemical and microbiological analyses}

\subsubsection{Thiobarbituric acid (TBA) analysis}

Manti sample (10 g) was homogenized with water. The mixture was transferred to a Kjeldahl flask and distilled by adding $2.5 \mathrm{~mL} 4 \mathrm{~N} \mathrm{HCl}$ (Merck, Germany) and $1 \mathrm{~mL}$ antifoam chemical. Five $\mathrm{mL}$ of TBA (Merck, Germany) and $5 \mathrm{~mL}$ of distillate were incubated in water bath at $80-90{ }^{\circ} \mathrm{C}$ for $30 \mathrm{~min}$ in a Bain-Marie equipment. The measurement was made on a spectrophotometer at $538 \mathrm{~nm}$ and obtained absorbance value was multiplied by 7.8 . The final value was presented as mg malondialdehyde (MDA) per kg of sample (Uzunlu 2011).

\subsubsection{Microbiological analysis}

\subsubsection{Inoculation of food-borne pathogens}

Food-borne pathogens [Escherichia coli (E. coli), Staphylococcus aureus (S. aureus), Salmonella typhimurium (S. typhimurium) and Listeria monocytogenes (L. monocytogenes)] were used to determine their survival in newly designed manti drying system. L. monocytogenes ATCC 7644, S. enterica subsp. enterica serovar. typhimurium ATCC 14028 and E. coli O157:H7 ATCC 33150 and $S$. aureus ATCC 25923 were provided by the Agricultural Control and Protection Center, Kayseri, Turkey. These strains were maintained at $-80{ }^{\circ} \mathrm{C}$, and the all microbial processes were conducted under the aseptic conditions. Before the inoculation, they were incubated in nutrient broth at $35{ }^{\circ} \mathrm{C}$ for overnight. After the incubation, culture turbidity was adjusted to $0.5 \mathrm{McF}$ arland standard. $10^{2}, 10^{4}$ and $10^{6}$ dilutions of adjusted cultures were used for inoculation of $25 \mathrm{~g}$ manti samples. Inoculated samples were treated with 17 different drying methods indicated in Table 1. After treatment, the samples were packaged in vacuum bags and stored at room temperature for 0 and 60 days before analysis. Before analysis, the manti samples were homogenized in isotonic solution with a ratio of 1:9. The homogenates were analyzed using suitable chromogenic solid medium for each organism. The chromogenic culture medias: E.coli $35^{\circ} \mathrm{C}$ Compact Dry EC chromogenic agar, blue colonies; $S$. aureus: $35^{\circ} \mathrm{C}$ Compact Dry X-SA chromogenic agar, light blue/ blue; L. monocytogenes: $37^{\circ} \mathrm{C}$ Compact Dry LS chromogenic agar, light blue/blue; Salmonella typhimurium: $41^{\circ} \mathrm{C}$ Compact Dry SL chromogenic agar, reddish purple or red colonies (AOAC 2012a; 2012b; 2012c; Pal et al 2007).

\subsubsection{Total bacterial counts}

The samples were prepared by homogenization of the manti samples with isotonic solutions at a ratio $1: 10$. For the inoculation of solid media, the sample solutions were diluted $\left(10^{0}, 10^{-1}, 10^{-2}\right.$ and $\left.10^{-3}\right)$ and $0.1 \mathrm{~mL}$ of dilutions were spread on the plates in triplicates. Plate Count Agar (PCA) was used for total aerobic mesophilic bacteria. The plates were incubated at $35^{\circ} \mathrm{C}$ for $24-48 \mathrm{~h}$, and microbial counts were expressed in Colony Forming Unit (CFU) $\mathrm{mL}^{-1}$.

\subsection{Statistical analysis}

SPSS version of 13.0 program was used for all statistical analyses with 95\% confidence interval. Data were analyzed by using student's t test and compared by multiple one-way analyses of variance (MANOVA) (Norusis 1993).

\section{Results and Discussion}

In this research, the effects of infrared (IR), ultraviolet (UV-C) and vacuum-drying applications on the manti quality were investigated either in alone or with their combinations, as alternative to conventional ovendrying method. For this purpose, an IR dryer was 
designed, and the samples were kept in drying system until their moisture contents were reduced to about $12 \%$ as in the case of industrial application. The effects of 17 different drying methods were observed considering the chemical and microbiological features of the manti samples, and the obtained results were summarized in following Tables.

\subsection{Ray density and energy consumption}

Ray densities of IR and UV-C lamps were measured by pyrometer after it had been reached to constant ray intensity. As seen in Table 1, while $500 \mathrm{~W}$ IR applications had the highest ray density which is about $2700 \mathrm{~W} \mathrm{~m}^{-2}, 250 \mathrm{~W}$ IR applications had the lowest one with $1100 \mathrm{~W} \mathrm{~m}^{-2}$ value. However, UV radiation was determined to have negative effects on the ray intensity. In a study about decontamination of cumin seeds by IR and UV-C methods, it was reported that while the ray intensity of IR was remaining stable in sole IR application, the use of UV radiation with IR reduced the intensity of IR (Erdogdu \& Ekiz 2011). Similar results were also obtained in this study (Table 1). IR drying system showed better results than the traditional methods in terms of energy consumption and investment cost (Table 1). Moreover, among the drying methods in terms of energy consumption, there was no significant difference.

\subsection{Thiobarbituric acid (TBA) analysis}

Manti is a sensitive food against oxidation and microbial deterioration, because it contains ground beef and semi-dry dough. With this aim, TBA analyses were conducted in the manti samples, and the results given in Table 2. As seen in Table 2, high TBA concentration is considered a sign of food deterioration resulted from lipid oxidation, because the TBA concentration increases with the increasing lipid per oxidation in foods (Janero 1990). Especially for meat and meat products, TBA concentration should not be exceeded $5 \mathrm{mg} \mathrm{L}^{-1}$, and it is also assured in Turkish Food Codex (Uzunlu 2011). The results showed that TBA values were increased after the radiation treatments. Additionally, the more the treatment combination increased, the more the TBA values of the manti samples increased. On the other hand, the highest value after two months of the storage was less than $3 \mathrm{mg} \mathrm{L}^{-1}$ (Table 2). In another study, it was reported that as the storage time of the manti samples increased, its TBA values was also increased (Uzunlu 2011). However, it has also been reported that the increase in TBA values in manti could not be directly correlated with the deterioration tested with sensory quality.

\subsection{Microbiological analysis}

In this study, for the determination of microbial quality, the effects and reliability of IR, UV-C and vacuum applications against some common food pathogens E.coli, S. aureus, L. monoytogenes ve $S$. typhimurium were investigated. Results of the treatments on four bacteria showed that even the sole application of $250 \mathrm{~W}$ IR was seemed to be efficient for the microbiological safety. Moreover, its combination with another treatment such as UV-C or vacuum made the application more assuring. Besides that, sole application of $500 \mathrm{~W}$ IR was enough for ensuring the food safety with no doubt, even if after 60 days of storage at room temperature. In another research, total mesophilic-aerobic bacteria count was determined in manti samples (Anonymous 2014). The results of the traditional or classical drying procedure applied in this study were the same that no microbial growth was observed. Therefore, the treatment applied in this study can be an alternative method in respect to classical method. The advantages of using IR were broadly mentioned in the literature (Sakai \& Hanzawa 1994; İçier \& Yildiz 2003; Sharma \& Verma 2005). In these researches, mainly leafy vegetables were used as a sample and compared to IR usage with commercial heat drying methods (Sakai \& Hanzawa 1994; İçier $\&$ Yild1z 2003). Their results showed that IR usage was more effective than that of the commercial method with respect to food quality. Moreover, they indicated that using IR drying system was cheaper than that of the commercial ones. In another study, Aslan (2012) indicated that IR application reduced the time needed for drying of the manti samples about $68 \%$ compared to traditional method, 250 ${ }^{\circ} \mathrm{C}$ heat treatment. Again, in this research, sole application of $500 \mathrm{~W}$ IR was enough to meet the microbiological criteria (Table 3). 
Table 2- Average thiobarbituric acid (TBA) concentrations in stuffed pasta (manti) samples, dried with different methods during the storage periods

\begin{tabular}{lccc}
\hline Drying types & & \multicolumn{2}{c}{ Thiobarbituric acid $\left(m g L^{-1}\right)$} \\
\hline FIR lamp* & \multicolumn{2}{c}{ Storage times } \\
\hline & 0. day & 30. day & 60. day \\
\cline { 2 - 4 } & $0.19 \pm 0.03^{\mathrm{Aa}}$ & $0.29 \pm 0.01^{\mathrm{Ab}}$ & $0.47 \pm 0.07^{\mathrm{Cc}}$ \\
& $0.15 \pm 0.02^{\mathrm{Aa}}$ & $0.34 \pm 0.03^{\mathrm{Ab}}$ & $0.86 \pm 0.05^{\mathrm{Ac}}$ \\
& $0.27 \pm 0.03^{\mathrm{Aa}}$ & $0.27 \pm 0.01^{\mathrm{Ab}}$ & $0.65 \pm 0.04^{\mathrm{Ac}}$ \\
& $0.15 \pm 0.02^{\mathrm{Aa}}$ & $1.05 \pm 0.02^{\mathrm{Ab}}$ & $0.87 \pm 0.07^{\mathrm{Ac}}$ \\
& $0.14 \pm 0.03^{\mathrm{Aa}}$ & $1.26 \pm 0.24^{\mathrm{Bb}}$ & $1.60 \pm 0.09^{\mathrm{Ac}}$ \\
& $0.16 \pm 0.01^{\mathrm{Aa}}$ & $0.78 \pm 0.03^{\mathrm{Ab}}$ & $1.19 \pm 0.06^{\mathrm{Bc}}$ \\
& $0.29 \pm 0.05^{\mathrm{Ba}}$ & $1.80 \pm 0.14^{\mathrm{Bb}}$ & $2.70 \pm 0.07^{\mathrm{Bc}}$ \\
\hline MDIR lamp $^{* *}$ & & & \\
\hline & $0.19 \pm 0.01^{\mathrm{Aa}}$ & $0.49 \pm 0.03^{\mathrm{Ab}}$ & $1.01 \pm 0.06^{\mathrm{Ac}}$ \\
& $0.14 \pm 0.07^{\mathrm{Aa}}$ & $0.73 \pm 0.05^{\mathrm{Ab}}$ & $1.28 \pm 0.16^{\mathrm{Ac}}$ \\
& $0.11 \pm 0.01^{\mathrm{Aa}}$ & $0.46 \pm 0.06^{\mathrm{Ab}}$ & $0.93 \pm 0.07^{\mathrm{Ac}}$ \\
& $0.15 \pm 0.02^{\mathrm{Aa}}$ & $0.59 \pm 0.03^{\mathrm{Ab}}$ & $0.86 \pm 0.03^{\mathrm{Ac}}$ \\
& $0.18 \pm 0.02^{\mathrm{Aa}}$ & $0.39 \pm 0.01^{\mathrm{Ab}}$ & $1.10 \pm 0.22^{\mathrm{Ac}}$ \\
& $0.18 \pm 0.02^{\mathrm{Aa}}$ & $0.46 \pm 0.01^{\mathrm{Ab}}$ & $1.41 \pm 0.10^{\mathrm{Ac}}$ \\
& $0.14 \pm 0.01^{\mathrm{Aa}}$ & $0.66 \pm 0.05^{\mathrm{Ab}}$ & $1.52 \pm 0.05^{\mathrm{Ac}}$ \\
& $0.12 \pm 0.01^{\mathrm{Aa}}$ & $0.66 \pm 0.05^{\mathrm{Ab}}$ & $1.49 \pm 0.07^{\mathrm{Ac}}$ \\
\hline Tradiational method & $0.14 \pm 0.05^{\mathrm{Aa}}$ & $0.50 \pm 0.14^{\mathrm{Ab}}$ & $0.60 \pm 0.07^{\mathrm{Ac}}$ \\
\hline (250 ${ }^{\circ}$ C for 30-35 min.) & & & \\
\hline
\end{tabular}

*, FIR Far-Infrared lamp; MDIR, Middle-Infrared lamp; **, M Mushroom Type IR lamp, B Bar Type IR lamp; UV-C, Ultraviyolet-C, $254 \mathrm{~nm} \lambda ; \mathrm{W}$, watt; ${ }^{\mathrm{ABC}}$, capital letters in the same column is the comparison of drying methods. There is no statistical difference between the drying methods represented by the same letters $(\mathrm{P}>0.05)$; ${ }^{\mathrm{abc}}$, Lowercase letters in the same line is the comparison of storage times. There is no statistical difference between the storage times represented by the same letters $(\mathrm{P}>0.05)$.

Table 3- Microbiological results of the stuffed pasta (manti) samples dried with different methods during the storage periods

\begin{tabular}{|c|c|c|c|c|}
\hline \multirow{2}{*}{$\begin{array}{l}\text { Application } \\
\text { name } \\
\text { FIR lamp }\end{array}$} & \multirow{2}{*}{ Drying type } & Pathogenic bacteria & \multicolumn{2}{|c|}{$\begin{array}{l}\text { Number of bacteria } \\
\quad\left(c f u 25 g^{-1}\right)^{*}\end{array}$} \\
\hline & & S. aureus & 10 & \\
\hline & 250 W M Type IR** & L. monocytogenes & 29 & - \\
\hline & 250 W M Type IR+UV-C & S. aureus & 1 & - \\
\hline & 250 W M Type IR+ vacuum*** & S. aureus & 8 & - \\
\hline & 250 W M Type IR+UV-C+ vacuum & S. aureus & 2 & - \\
\hline & 500 W B Type IR** & - & - & - \\
\hline & 500 W B Type IR+UV-C & - & - & - \\
\hline & 500 W B Type IR+ vacuum & - & - & - \\
\hline & 500 W B Type IR+UV-C+ vacuum & - & - & - \\
\hline & 250 W B Type IR & S. aureus & 2 & - \\
\hline MDIR lamp & 250 W B Type IR+UV-C & L. monocytogenes & - & - \\
\hline & 250 W B Type IR+ vacuum & L. monocytogenes & 3 & - \\
\hline & 250 W B Type IR+UV-C+ vacuum & - & - & - \\
\hline & 500 W M Type IR & - & - & - \\
\hline & 500 W M Type IR+UV-C & - & - & - \\
\hline & 500 W M Type IR+ vacuum & - & - & - \\
\hline & 500 W M Type IR+UV-C+ vacuum & - & - & - \\
\hline Traditional method & $250{ }^{\circ} \mathrm{C}$ for $30-35 \mathrm{~min}$ & E. coli & 42 & 6 \\
\hline
\end{tabular}




\section{Conclusions}

The effects of infrared (IR), ultraviolet-C (UV-C) and vacuum-drying applications on some quality features of manti samples were researched either in alone or combinations, as alternative to conventional method. Moreover, except for $500 \mathrm{~W}$ Bar Type IR; lamp type of IR has no effect on the microbiological properties and TBA values of manti. Also, as the power of the lamps increases, the TBA values and microbial qualities of manti samples have increased.

The results showed that traditional drying method needs higher initial investment cost and energy consumption compared to IR drying methods. Moreover, a combined drying system consisting of IR, UV-C and vacuum could be more beneficial in terms of qualitative properties of the manti. In conclusion, it might be suggested that although sole application of $500 \mathrm{~W}$ IR was enough to meet microbiological quality for manti, in general, the results showed that IR combined with UV-C and vacuum applications can be a better alternative to traditional methods in commercial manti drying practices.

\section{Acknowledgements}

This study was financially supported by the Commission of Scientific Research Projects, Erciyes University with a grant (FDK-2014-4806).

\begin{tabular}{|ll|}
\hline \multicolumn{2}{|l|}{ Abbreviations and Symbols } \\
\hline$I R$ & Infrared \\
$U V-C$ & Ultraviyolet-C \\
Manti & Stuffed Pasta \\
\hline
\end{tabular}

\section{References}

Anonymous (2014). Turkish Food Codex, Microbiological Criteria Communiqué. 2010/16

AOAC (2012a). Certificate No. 081001 Tokyo 110-8736 Japan

AOAC (2012b). Certificate No. 110402 Tokyo 110-8736 Japan

AOAC (2012c). Certificate No. 3SAQ-042 Tokyo 1108736 Japan
Aslan N (2012). İnfrared kurutma yönteminin kurutulmuş mantı kalitesi üzerine etkisi. Master Thesis, Çanakkale Onsekiz Mart University (Unpublished), Turkey

Cayot N (2007). Sensory quality of traditional foods. Food Chemistry 101: 154-162

Erdogdu S B \& Ekiz H I (2011). Effect of ultraviolet and far IR radiation on microbial decontamination and quality of cumin seed. Journal of Food Science 76(5): M284-M292

Farkas J (1990). Combination of radiation with mild heat treatment. In: Radiation and combination treatments. Conference. March 1-2, London, England, pp. 223229

Gallegos-Infante J A, Rocha-Guzman N E, GonzalezLaredo R F, Ochoa-Martinez L A, Corza N, BelloPerez L A, Medina-Torres L \& Peralta-Alvarez L E (2010). Quality of spaghetti pasta containing mexican common bean flour (Phaseolus vulgaris L.). Food Chemistry 119: 1544-1549

Gokmen S, Aydin M F, Sayaslan A \& Yetim H (2014). The effect of UV radiation on the mycotoxin content of ravioli. In: Proceedings of the International Conference on Computational and Experimental Science and Engineering (ICCESEN), 25-29 October, Antalya, Turkey, pp. 14

Gokmen S, Aydin M F, Kocabas A, Sayaslan A, Yetim H \& Caglar A (2015). A Study on quality criteria of commercial stuffed pasta (manti), as traditional food. International Food Research Journal 22(5): 20182024

Heldman D R \& Lund D B (2007). Handbook of Food Engineering. CRC Press Book, London.

İçier F \& Yıldız H (2003). Elektriksel yöntemlerin gıdalarin kalite özellikleri üzerine etkileri. Gıda 30(4): 255-260

Janero D R (1990). Malondialdehyde and thiobarbituric acid-reactivity as diagnostic indices of lipid peroxidation and peroxidative tissue injury. Free Radical Biology and Medicine 9(6): 515-540

Norusis M J (1993). SPSS: SPSS for Windows, Base System User's Guide Release 6.0. SPSS Inc., Chicago.

Pal S, Kyung Y \& Song M (2007). Does the antibacterial activity of silver nanoparticles depend on the shape of the nanoparticle. a study of the gramnegative bacterium Escherichia coli. Applied and Environmental Microbiology 73(6): 1712-1720 
Sakai N \& Hanzawa T (1994). Applications and advances in far-IR heating in Japan. Trends in Food Science Tecnology 5(11): 357-362

Sharma G P \& Verma P B (2005). Mathematical modeling of infrared radiation thin layer drying of onion slices. Journal of Food Engineering 67: 361-366

Singh M \& Goswami T K (2003). Role of feed rate and temperature in attrition grinding of cumin. Journal of Food Engineering 59: 285-290

Sitti S (2011). Effect of vacuum and modified atmosphere packaging on some of the quality characteristics of kayseri manti. Master Thesis, Erciyes University (Unpublished), Turkey

Uzunlu S (2011). Modified atmosphere packaging of manti with different gas compositions and its microbial and chemical composition variances during cold storage. PhD Thesis, Çukurova University (Unpublished), Turkey

Varlık C, Erkan N, Özden Ö, Mol S \& Baygar T (2004). Su Ürünleri İşleme Teknolojisi. İstanbul Üniversitesi Yayınları, İstanbul 